\title{
Size and Carbohydrate Content of Ears of Baby Corn in Relation to Endosperm Type ( $S u, s u$, se,
} $\operatorname{sh} 2$ )

\author{
A. Bar-Zur \\ Field Crops Institute, Agricultural Research Organization, Newe Ya' ar Experiment Station, P.O. \\ Haifa 31999, Israel
}

\author{
A. Schaffer \\ Field Crops Institute, Agricultural Research Organization, Department of Vegetables and Genetics, \\ P. 0. Box 6, Bet Dagan 50250, Israel
}

Additional index work maize, sweet corn, carbohydrates, Zea mays

\begin{abstract}
Ear size and quality traits of various types of maize (Zea mays L.) ( $\mathrm{Su}$, su, se, sh2 ) used as baby corn were evaluated in field experiments. Ear size increased with time (0 to 6 days) after silking. Optimal stage for harvest was at silking for most cultivars and 6 days after silking for the prolific mini-corn cultivars. Sugar content of baby corn ears of all genotypes consisted primarily of glucose and fructose, with only low levels of sucrose. There was no significant increase in sugar content attributable to the su, se, or sh2 genes compared with $S u$, thus indicating there is no reason to use sweet corn types instead of the higher-yielding $S u$ types. Total soluble sugar content of the genotypes ranged from $\approx 20$ to $30 \mathrm{mg} \cdot \mathrm{g}^{-1}$ fresh weight. Starch and water-soluble polysaccharide (WSP) concentrations in the $\mathrm{Su}$ cultivars, which were higher than those in the other endosperm types studied, decreased slightly from 0 to 6 days after silking. However, WSP concentrations were low and not likely to affect quality. Crispness, determined by organoleptic tests, decreased with time of harvest and differed among genotypes.
\end{abstract}

Baby corn ears are popular as canned ears or with stir-fried vegetables in Chinese-American and European restaurants (Galinat, 1985). Recently, a market for fresh baby corn ears in trays has emerged in Europe, mainly for use as a decorative, crisp vegetable in salads. Production is based primarily on hand picking of sweet corn ears at silk emergence, or selective picking, that enables harvest of multiple-ear shoots in prolific starchy maize hybrids (Galinat and Lin, 1988). Market requirements generally limit ear size to a 4.5 to $10-\mathrm{cm}$ length and 7 - to 17 $\mathrm{mm}$ diameter. Ear size is also limited by changes in moisture content and crispness with time after silking. Most production is located in the Far East. The main cultivars are either prolific starchy ( $S u$ ) feed corn types or supersweet ( sh2) cultivars (Galinat and Lin, 1988). In practical terms, cultivars are grown under either high population density, for baby corn only, or lower population density where the first ear is picked for baby corn and the second ear is left intact for further development as sweet or field corn. Recently, three unique Sugary $(S u)$ prolific baby corn cultivars have been introduced (Bar-Zur and Saadi 1990). These cultivars bear three to five small ears that silk within 1 to 2 days on a single stalk. To reach the required marketable size, ears must be picked 3 to 4 days after silking in early season plantings (Bar-Zur and Saadi, 1990), or later if harvested during the fall.

To the best of our knowledge, the impact of endosperm type on carbohydrate $(\mathrm{CHO})$ content of baby corn has not yet been reported. Gonzales et al. (1976) studied kernel CHO content during ear development of four endosperm types (Starchy, sugary, sugary enhanced, and shrunken) beginning 14 days after

\footnotetext{
Received for publication 30 Dec. 1991. Accepted for publication 13 May 1992. This project was supported in part by Galilee Seeds, "Peri" Project no, 801. Contribution no. 3382-E, 1991 series from the Agricultural Research Organization, Bet Dagan, Israel. We thank D. Barnea, R. Padova, Miriam Fugelman, Z. Benei-Moshe, and A. Meyer, who carried out the field experiments and laboratory evaluations. The cost of publishing this paper was defrayed in part by the payment of page charges. Under postal regulations, this paper therefore must be hereby marked advertisement solely to indicate this fact.
}

pollination. Ferguson et al. (1979) began their study of kernel $\mathrm{CHO}$ at 19 days. Carey et al. (1982) reported an elevated sugar profile in seeds of sugary enhanced ( suse ) genotypes, compared with sugary $(s u)$, but not in other plant tissues.

The objectives of this study were to: 1) evaluate the adaptability of cultivars from diverse sources for baby corn production, and 2) study the impact of endosperm type on $\mathrm{CHO}$ content and quality of baby corn ears.

\section{Materials and Methods}

Two sets of cultivars were evaluated at Newe Ya'ar Experiment Station in Israel, during Summer 1989 and 1990. In the first experiment, six cultivars were planted at the end of the summer, on 18 Aug. 1989. Temperature during silking was moderate (24C maximum day, 15C minimum night) and was characterized by slowed development of ear shoots. The experiment was arranged in a completely randomized block, with four replicates, two rows of $3.2 \mathrm{~m}$ per replicate, and seven plants per meter. The cultivars were: 'Jubilee' ( $s u$ ), JH2283 ( $s u$ ), and JH2105 ( su ) from Rogers NK, 'Classic R32' ( suse ) from Asgrow, 'Summer Sweet 7200' ( sh2 ) from Abbott and Cobb, and NY573 ( $S u$ ), a prolific type with small ears developed at the Newe Ya'ar Experiment Station. The ear shoots of one row in each replicate were covered with plastic bags before silk emergence to avoid pollination, whereas those in the other row were left uncovered for open pollination. Date of silking was marked on each plant. Ears from both rows were picked at 0, 2, 4, and 6 days after silking. Four ears, one from each replicate and harvest date, were husked, weighed, measured, and cut lengthwise. One half was used for dry-matter determination and preliminary assessment of crispness by an organoleptic panel composed of four untrained individuals. The second half was frozen in liquid nitrogen and freeze-dried before ethanolic extraction for $\mathrm{CHO}$ determination, as noted below. This analysis

Abbreviations: CHO, carbohydrate; WSP, water-soluble polysaccharides. 


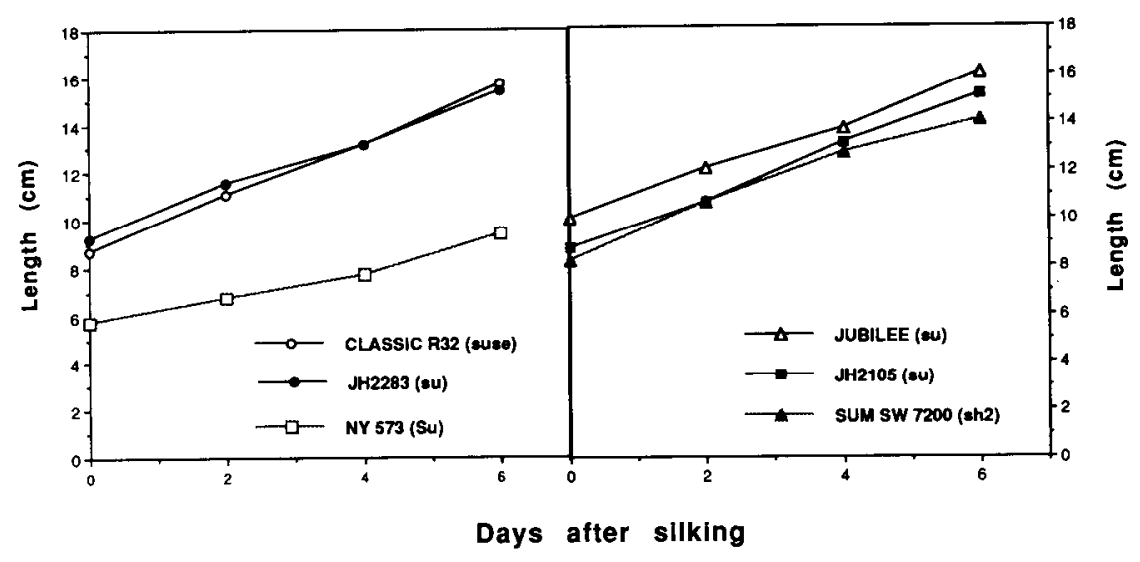

Fig. 1. Ear length of baby corn ear shoots in relation to date after silking, 1989 experiment. No significant differences were observed in ear length between fertilized and unfertilized ears.

Table 1. The effect of harvest date on crispness $^{2}$ of unfertilized baby corn ears.

\begin{tabular}{lcccc}
\hline \hline & \multicolumn{4}{c}{ Days after silking } \\
\cline { 2 - 5 } Cultivar & 0 & 2 & 4 & 6 \\
\hline Classic R32 (suse) & $4.0 \mathrm{a}^{\mathrm{y}}$ & $4.0 \mathrm{a}$ & $3.0 \mathrm{ab}$ & $2.1 \mathrm{~b}$ \\
Jubilee $(s u)$ & $3.9 \mathrm{a}$ & $3.7 \mathrm{a}$ & $2.9 \mathrm{ab}$ & $2.7 \mathrm{a}$ \\
NY573 $(S u)$ & $4.0 \mathrm{a}$ & $3.9 \mathrm{a}$ & $3.7 \mathrm{a}$ & $2.7 \mathrm{a}$ \\
SUM SW 7200 (sh2) & $4.0 \mathrm{a}$ & $2.9 \mathrm{~b}$ & $2.6 \mathrm{~b}$ & $1.6 \mathrm{~b}$ \\
\hline
\end{tabular}

${ }^{2} 4$, crisp and fragile; 3 , crisp, acceptable; 2 , tough; 1 , very tough. 'Mean separation within columns by multiple range test, $P=0.05$.

was performed on nonfertilized ears only. Because crispness and $\mathrm{CHO}$ analysis of the three sugary cultivars were similar, only those for 'Jubilee' are presented.

In the second experiment, two cultivars were planted on 22 May 1990 in a completely randomized design with four replicates, two rows of $3.2 \mathrm{~m}$ per replicate, and seven plants per meter. The cultivars were NY569 $(\mathrm{Su})$, a prolific cultivar with small ears developed at Newe Ya'ar Experiment Station, and 'Florida Stay Sweet' (sh2) from Illinois Foundation Seeds. One row was harvested at the optimal stage (of each cultivar) for baby corn marketing. Total yield, net yield (husked ears), marketable ears (4.5 to $10 \mathrm{~cm}$ long), and ear count were determined. In the second row, ears were bagged and marked as described in the first experiment. Ears were harvested at 0, 2, 4, and 6 days after silking. The procedure for quality evaluation was as described for the first experiment, except that samples were immediately heated in $80 \%$ ethanol for $5 \mathrm{~min}$ before storage.

Tissue $(\approx 2 \mathrm{~g}$ fresh weight) was extracted five times in hot $80 \%$ ethanol to remove soluble sugars, which were separated by high performance liquid chromatography (HPLC) as in Miron and Schaffer (1991), using a Bio-Rad Fast Carbohydrate Column with double-distilled $\mathrm{H}_{2} \mathrm{O}$ as solvent, according to manufacturer's directions. Sucrose, fructose, and glucose were identified by their retention times and quantified according to standards. To determine the absence of maltose, sugars were separated on an amino column (Alltech, Deerfield) under conditions separating sucrose from maltose (acetonitrile : $\mathrm{H}_{2} \mathrm{O}, 85: 15$, $\mathrm{v} / \mathrm{v})$.

Residue from the $80 \%$ ethanol extractions was extracted three times in $10 \%$ ethanol to remove water soluble polysaccharides (WSP) (Garwood et al., 1976). After enzymatic hydrolysis by amyloglucosidase (EC 3.2.1.3) (Sigma, St. Louis), the solubilized WSP was quantified by dinitrosalicylic acid (Sumner, 1921).
Residue from the $10 \%$ ethanol was assayed for starch after hydrolysis by amyloglucosidase (Thivend et al., 1973), and quantified by dinitrosalicylic acid. Four ears from each variety were sampled, their size measured, and analized for $\mathrm{CHO}$ content. Statistical analysis was by $\mathrm{F}$ test at $P=0.05$.

\section{Results and Discussion}

When baby corn ears were picked at the optimal date for each cultivar, the marketable yield of NY569 and NY573, the prolific starchy $(\mathrm{Su})$ cultivars with mini-corn ears, significantly exceeded that of the other cultivars (data not shown). These results are in agreement with previous observations, indicating that the multiple-eared type, specifically bred for baby corn, outyields conventional cultivars currently on the market (Bar-Zur and Saadi, 1990). Since the ear shoot of most corn cultivars develops quite rapidly after silking and reaches an undesirable length $(>10 \mathrm{~cm})$ for baby corn (Fig. 1), the optimal harvest period is very short. All cultivars tested in the 1989 experiment, excluding NY573, had to be harvested at silking to meet the size requirement. The prolific cultivar NY573, which is characterized by small ears, reached the desired size 6 days after silking. Silking in this experiment occurred during the fall, when temperatures were moderate, and ear shoot growth was slow. Differences between bagged and open-pollinated ear shoots were negligible (data not shown). Baby corn ears are known to be crisp, if not too fragile, at silking. Crispness of baby corn ears, as evaluated by bite tests of the raw ears, declined with time after silking (Table 1). Preliminary observations have shown a tendency toward reduced crispness in ear shoots that have been pollinated, as compared with unfertilized ones, but only at 6 days after silking, whenmost standard cultivars tend to be too tough to be eaten fresh, whether fertilized or not.

$\mathrm{CHO}$ content is a major factor determining quality of sweet corn and may also have an impact on flavor and quality of baby corn ears. We, however, did not find important differences in sugar content related to endosperm type (among genotypes) in young unfertilized ears during the first 6 days after silking. The major sugars observed in all genotypes studied were the reducing sugars, glucose and fructose, in about equal amounts of 10 to $15 \mathrm{mg} \cdot \mathrm{g}^{-1}$ fresh weight (Fig. 2). Sucrose was present in only small amounts at silking, with an even further decline over the next 4 days. This sugar profile (reducing sugar : sucrose, 4:1), present in all genotypes, is characteristic of actively growing tissue that has not yet reached the stage of sucrose accumulation. Gonzales et al. (1976) have shown that even as late as 14 days 


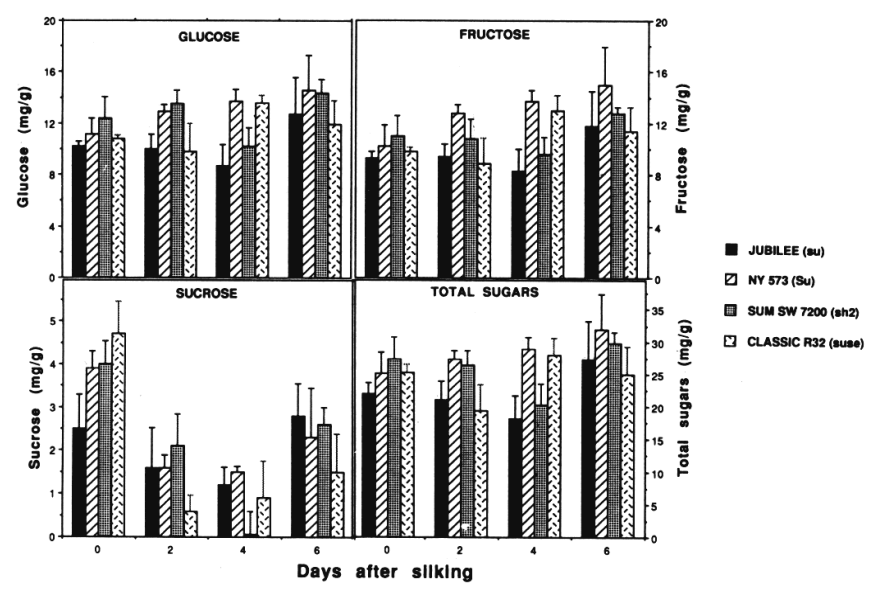

Fig. 2. Sugar content in developing ear shoots of unfertilized corn ears of endosperm types $\mathrm{Su}, \mathrm{su}, \mathrm{se}, \mathrm{sh} 2$. Sugar profiles of the $s u$ cultivars that are not included were similar to Jubilee $(\mathrm{su})$. Vertical bars indicate SE at $P=0.05$.

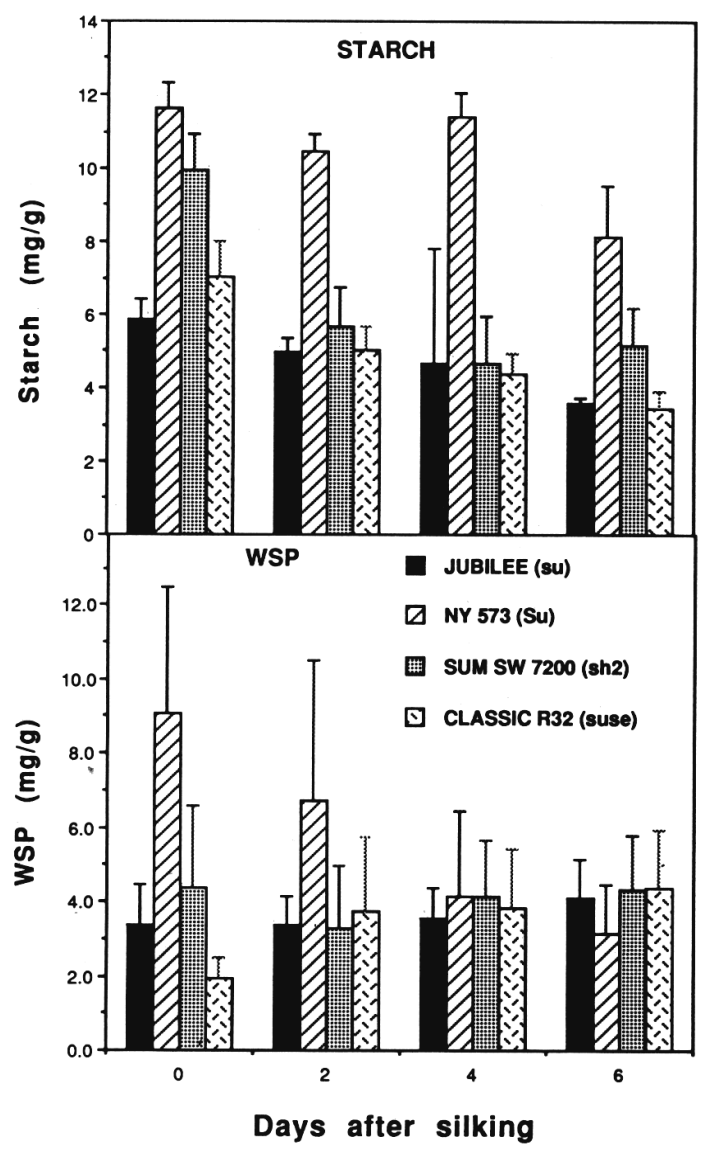

Fig. 3. Starch and WSP content in developing ear shoots of unfertilized corn ears of endosperm types $\mathrm{Su}, \mathrm{su}$, se, and sh2 during early stages of ear development, 1989 experiment. Vertical bars indicate $\mathrm{SE}$ at $P=0.05$.

after pollination, the reducing sugar : sucrose ratio of kernels was $\approx 1: 1$ for $S u, s u$, and suse cultivars, and $\approx 2: 1$ for a $\operatorname{sh} 2$ cultivar. In that study, sucrose levels reached a peak accumulation only 18 days after pollination and afterward declined. Similar data were presented by Creech (1968).

Total sugar content ranged from $\approx 20$ to $30 \mathrm{mg} \cdot \mathrm{g}^{-1}$ fresh

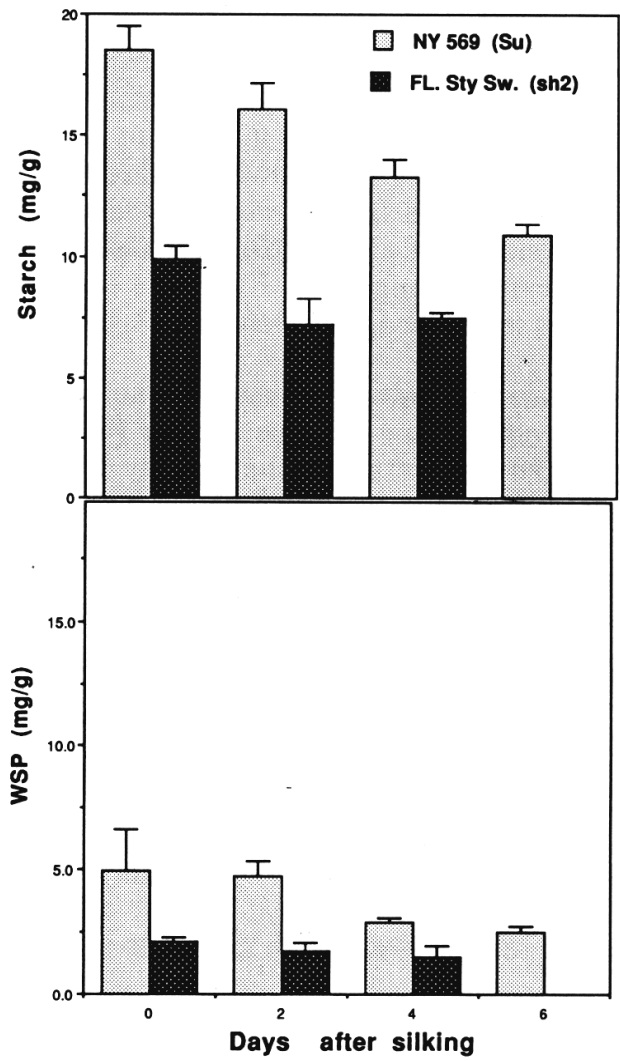

Starch and WSP content in developing ear shoots of unfer$\mathrm{d} S u$ and $s h 2$ corn ears during early stages of ear development, experiment. Vertical bars indicate SE at $P=0.05$.

weight in all the cultivars studied (Fig. 2). The prolific starchy cultivar NY573 showed a slight, nonsignificant increase in sugar content throughout development. An identical trend was observed in the second experiment, when NY569 (Su) and 'Florida Stay Sweet' ( $s h 2$ ) were compared (data not shown). The prolific $\mathrm{Su}$ cultivar at 6 days after silking (optimum harvest stage) had a slightly higher total sugar content (32 $\mathrm{mg} \cdot \mathrm{g}^{-1}$ fresh weight) than the other cultivars at their optimal harvest stage (silking, 22 to $27 \mathrm{mg} \cdot \mathrm{g}^{-1}$ fresh weight). However, the total sugar concentrations of $\approx 30 \mathrm{mg} \cdot \mathrm{g}^{-1}$ fresh weight were significantly lower than those commonly observed in sweet corn kernels, even those of $s u$ genotypes (Creech, 1968; Evenson and Boyer, 1986; Ferguson et al., 1979; Garwood et al., 1976; Gonzales et al., 1976). Therefore, modest increases in soluble sugar concentration in the range of $30 \mathrm{mg} \cdot \mathrm{g}^{-1}$ fresh weight are not likely to dramatically affect quality.

Starch content was significantly higher in the $S u$ cultivars NY573 and NY569 than in the others, which were about equal in starch content; except for NY569, it varied little throughout the 6 days studied (Figs. 3 and 4). Gonzales et al. (1976) reported that at 14 days, $S u$ kernels had more than twice the starch content of $s u$ kernels $\left(\approx 45\right.$ and $20 \mathrm{mg} \cdot \mathrm{g}^{-1}$ fresh weight, respectively, calculated from their data), while the suse and sh2 kernels did not show significant starch accumulation until 18 days. The higher starch level in young $S u$ cob also may be characteristic of the immature ears, as it is of the developing kernels. We do not know to what extent the higher starch content influences the quality of baby corn; however, it had no noticeable effect on the evaluation given by the organoleptic panel (not presented). This panel did not report the increase in 
floury texture that is generally reported with starch levels significantly higher than the $20 \mathrm{mg} \cdot \mathrm{g}^{-1}$ fresh weight observed here.

WSP content was low (Figs. 3 and 4), similar to levels observed in endosperm of genotypes that do not accumulate WSP (Garwood et al., 1976). The somewhat higher WSP at 0 and 2 days in the Su cultivars that do not accumulate WSP in the endosperm (Gonzales et al., 1976), as compared with the $s u$ and suse cultivars, is enigmatic. From this study, we cannot determine whether there is physiological significance to this observation.

Moisture content of baby corn ears was not affected significantly by harvest time or endosperm type (data not shown). Thus, acceptable freshness-another quality trait-was maintained in all genotypes during the 6-day harvest. However, the decline in crispness of baby corn ears (Table 1) is apparently related to an increase in structural $\mathrm{CHO}$.

The results of these experiments indicate that the $s u$, suse, and $s h 2$ sweet corn types we studied have no significant advantage over the $\mathrm{Su}$ genotype with respect to $\mathrm{CHO}$ content and related quality in baby corn. Rather, all cultivars studied had similar CHO profiles characteristic of actively growing sink tissue at the presucrose accumulation stage. Small differences in WSP content are not likely to influence quality, and the higher starch content in the $S u$ cultivars is unlikely to detract from quality. Therefore, it would appear that the advantages of the prolific starchy $(\mathrm{Su})$ cultivars, with respect to yield, can be used freely.

\section{Literature Cited}

Bar-Zur, A. and H. Saadi. 1990. Prolific maize hybrids for baby corn. J. Hort. Sci. 65(1):97-100.
Carey, E.E., D.B. Dickinson, L.Y. Wei, and A.M. Rhodes. 1982. Occurrence of sorbitol in Zea mays. Phytochemistry 21:1909-1911.

Creech, R.G. 1968. Carbohydrate synthesis in maize. Adv. Agron. 20:275-322.

Evenson, K.B. and C.D. Boyer. 1986. Carbohydrate composition and sensory quality of fresh and stored sweet corn. J. Amer. Soc. Hort. Sci. 111:734-738.

Ferguson, J.E., D.B. Dickinson, and A.M. Rhodes. 1979. Analysis of endosperm sugars in a sweet corn inbred (IL677a) which contains the sugary enhancer (se) gene and comparison of se with other corn gene types. Plant Physiol. 63:416-420.

Galinat, W.C. 1985. Whole ear baby corn: A new way to eat corn. Proc. Northeast Corn Improvement Conf. 40:22-27.

Galinat, W.C. and R.Y. Lin. 1988. Baby corn: Production in Taiwan and future outlook for production in the United States. Econ. Bot. 42:132-134.

Garwood, D.L., F.J. McArdle, S.F. Vanderslice, and J.C. Shannon. 1976. Postharvest carbohydrate transformations and processed quality of high sugar maize genotypes. J. Amer. Soc. Hort. Sci. 101:400404

Gonzales, J.W., A.M. Rhodes, and D.B. Dickinson. 1976. Carbohydrate and enzymic characterization of high sucrose sugary inbred lines of sweet corn. Plant Physiol. 58:28-32.

Miron, D. and A.A. Schaffer. 1991. Sucrose phospate synthase, sucrose synthase, and invertase activities in developing fruit. Lycopersicon esculentum Mill. and the sucrose accumulating Lycopersicon hirsutum Humb. and Bonpl. Plant Physiol. 95:623-627.

Sumner, J.B. 1921. Dinitrosalicylic acid: A reagent for estimation of sugar in normal and diabete urine. J. Biol. Chem. 47:57.

Thivend, P., C. Merrier, and A. Guilbot. 1973. Determination of starch with glucoamylase, p. 100-105. In R.L. Wistler and J.N. BeMiller (eds.). Methods in carbohydrate chemistry, vol. 6. Academic, New York. 